\title{
Influences of the climacteric period on the conjugal relationship: gender perspective
}

\author{
Influências do climatério em relacionamentos conjugais: perspectiva de gênero
}

Mariana Lustosa de Carvalho ${ }^{1}$, Fernando José Guedes da Silva Júnior ${ }^{1}$, Adriana da Cunha Menezes Parente ${ }^{1}$, Jaqueline Carvalho e Silva Sales ${ }^{1}$

Objective: to analyze the influence of the climacterium on the marital relationship from a perspective of gender. Methods: qualitative study based on the gender theory, with 20 climacteric women, using interviews and thematic analysis. Results: three categories emerged: Affection, companionship, understanding, respect and dialogue: positive influences of the climacterium on the relationship of the couple; Influence of the climacterium on sexual activity and its interface with the marital relationship; and Estrangement in the conjugal relationship influenced by the climacterium. The positive influences of the climacterium on the marital relationship highlight greater affection, companionship, understanding, respect and dialogue; the climacterium influences the couple due to changes in sexual activity; estrangement in the marital relationship derived from changes in companionship and routine. Conclusion: the climacterium positively influences the marital relationship. However, due to the symptoms of this phase, there are changes in sexual activity that contribute to the estrangement of the couple. Descriptors: Climacteric; Marriage; Women's Health.

Objetivo: analisar a influência do climatério em relacionamentos conjugais sob a perspectiva de gênero. Métodos: estudo qualitativo, fundamentado na teoria de gênero, realizado com 20 mulheres climatéricas. Dados coletados por meio de entrevistas e submetidos à análise temática. Resultados: emergiram três categorias: Carinho, companheirismo, compreensão, respeito e diálogo: influências positivas do climatério no relacionamento conjugal; Influência do climatério na atividade sexual e sua interface com o relacionamento conjugal; e distanciamento no relacionamento conjugal influenciado pelo climatério. Os relatos das influências positivas do climatério no relacionamento conjugal destacam a intensificação do carinho, companheirismo, compreensão, respeito e diálogo; o climatério influencia o relacionamento conjugal devido às alterações na atividade sexual; o distanciamento no relacionamento conjugal ocorreu em virtude das mudanças do companheiro e rotina do casal. Conclusão: o climatério influencia positivamente o relacionamento conjugal. Mas, devido aos sintomas desta fase, há mudanças na atividade sexual que contribuem para o distanciamento do casal.

Descritores: Climatério; Casamento; Saúde da Mulher.

\footnotetext{
${ }^{1}$ Universidade Federal do Piauí. Teresina, PI, Brazil. 


\section{Introduction}

The increase in life expectancy associated with improved health conditions has resulted in a growing population increase, especially of women, which is explained by the biological elements of female hormonal defense, the lower vulnerability of women to factors that cause mortality, mainly external causes, and their early search for health services ${ }^{(1)}$.

In Brazil, women represent $51.5 \%$ of the population, and $32.0 \%$ of them are between the ages of 35 and 65 . In this context of increased life expectancy, women experience several stages of the life cycle, among which is the significant phase of the climacterium. Thus, public health policies that consider them in all phases of life are necessary ${ }^{(2-3)}$.

The climacterium corresponds to the transition between reproductive and non-reproductive stages. It usually begins at 40 and ends at age 65 . The milestone of this phase is the menopause, characterized by the definitive interruption of menstruation for 12 consecutive months ${ }^{(4)}$.

The physical, hormonal and psychological changes present in the climacteric phase can result in significant impact on the female sexuality and interaction with the partner. It is important to emphasize that sexuality is not synonymous with sex, since it is not restricted to the sexual act. Its manifestation occurs according to the cultural aspects of each individual, be it by caresses, kisses, sensuality, among other forms of expression ${ }^{(5)}$.

The changes and their impacts on sexuality are relevant issues. The knowledge produced on these theme is quite broad. In this sense, the understanding of how the changes coming from the climacteric period are intertwined with the conjugal relationship is a lacuna that must be explored ${ }^{(6)}$, since it is affirmed that the influence of this phase on the conjugal relationship is inevitable, however unique because it depends on how each couple experiences their own relationship and how adjustments are made in all the other phases of the transition ${ }^{(6-7)}$.

Therefore, continuous monitoring of climacteric women, with a view to promoting health, diagnosis and early treatment, unique in this phase, is considered necessary. The Family Health Strategy is an important space to offer adequate assistance to women and couples in the climacteric period, because it allows the re-signification of health care knowledge and practices. It should be noted that the support of the partner in actions directed to the climacteric period contributes positively to the woman's experience of this period ${ }^{(8)}$.

In view of the presented reality, the objective was to analyze the influence of the climacteric period on the conjugal relationship from the perspective of gender.

\section{Methods}

This is a qualitative study based on the theory of gender, which is grounded on dynamic senses built in the power relations that support the connections between men and women. Distinctions between sexes occur in all cultures, but they result in different social and psychological particularities in contexts and categories of similar historical situations ${ }^{(9)}$.

The present research was carried out at a Basic Health Unit of Teresina, Piauí, Brazil. The participants of this study were 20 women who met the inclusion criteria: age group 40 to 65 years, enrolled in the basic health unit of the study, married or common-law married, and information in the medical record that characterized the climacteric period.

The definition of the number of study participants was mediated by the process of data saturation. The number of participants is not defined a priori, and the inclusion of new participants is interrupted when conceptions, explanations and meanings expressed by the deponents become regular ${ }^{(10)}$. 
A semi-structured script with open questions was used as instrument for data collection. The script allowed to know the women and the climacteric influences on the conjugal relationship. The collection was started with two triggering questions: tell me about your life in the climacteric period; and how is your marital relationship at this stage?

A Mp3 device was used to record the reports, after acceptance by the participants. Data collection took place from January to March, 2018, through interviews conducted in the unit's medical offices, with an average duration of 30 minutes.

Data were organized and treated according to the thematic analysis technique ${ }^{(10)}$, which consists of discovering the nuclei of meaning that make up the discourses, in which the presence and frequency bring meaning to the object studied.

The analysis and discussion of the data of the categories were supported in the concepts and conceptions on the subject. To preserve the anonymity of the participants, we used the letter "I" (I1, I2, I3 ...) in the course of the discussion, indicating the word interviewee.

The study followed the ethical and legal requirements of Resolution no 466/12, and was approved by the Research Ethics Committee of the Federal University of Piauí, according to opinion no 2,445,699.

\section{Results}

Of the study participants, 18 were married and two common-law married, with nine to 46 years of relationship. After reading and analyzing the speeches, three thematic categories related to climacteric influences on the conjugal relationship emerged: Affection, companionship, understanding, respect and dialogue: positive influences of the climacterium on the relationship of the couple; Influence of the climacterium on sexual activity and its interface with the marital relationship; and Estrangement in the conjugal relationship influenced by the climacterium.

\section{Affection, companionship, understanding, respect and dialogue: positive influences of the climacte- rium on the relationship of the couple}

This category showed attitudes that demonstrated help and support offered by the husband to the woman in the climacteric phase. The intensification of expressions of affection, companionship and understanding was observed in the statements of the deponents. He is even more affectionate because there are times that I lose patience with my mother, I lose my temper very easily, and he becomes more affectionate (I3). He helps me, works, looks after the girls, he is a good father. He is a good husband, he supports me, he is affectionate, sometimes he hugs me, he kisses me (I17). In general, my marriage is good, we have understanding with each other, we have the conversation, we have sense of humor. He is very friendly, helpful, tender, if I need him, he is there. He became more affectionate, more helpful with me, I think it is related to this period, because before that he did not use to do it, and today he has improved a lot (I9).

Seeing the symptoms presented by some women in the climacteric phase, the companions demonstrated understanding of these possible changes. This shows the spouse's involvement in this period. The partner's understanding of the changes that occur in this phase, too, can be seen in these lines. I can say he's understanding. In this regard, he understands this process. But when I'm crying, he does not complain either. Sometimes in our discussions, I even cry, and he stares at me, but does not call me a crying woman in our day-to-day discussions. But he does not criticize (I5). We are well, one understanding the other, we are very friends, one understands the other and we are well as husband and wife. He has always helped me, he is a calm person, I am more irritated, some days I feel even more stressed, and he keeps quiet, calm. When I feel things, he stays on his own, he understands, he is very understanding (I19). My husband understands me very well, he is a companion who understands me, he knows my problem and does not force me to do anything, only when I am feeling really better, we talk, he is a very good friend. When I was stressed, I would curse my grandchildren, put the food on the plate, and cried because I did not feel like eating, my husband even lost weight as well, and he would talk to my daughter, what do I do with your mother, because your mother will disappear and I will die 
too, because she is my life. When I get ready to dance, he feels happy and says that's a good thing that I'm returning, he takes me to a walk, slowly, at my pace (I20).

Respect throughout the relationship was also reported in the speech of one of the deponents, demonstrating a positive influence of the climacterium on the conjugal interaction. He always respected me, he was never a man who cursed me, never cursed my family, he always respected me (I1).

The following statements express that the dialogue between the couple was built during the conjugal relationship and that, in the climacteric phase, with the manifestations of the symptoms, it represented a strategy that allowed understanding, reconciliation and sharing among spouses. We have a lot of dialogue. I am different, I am not affectionate and he keeps asking a lot from me in this aspect, because I am not affectionate with him, he is more affectionate than me. He treats me well, there are those husbands who wake you up giving you kisses, well, he's like that, he wakes me up and kisses me. We have a a very good communication, and we need one another. He is sympathetic, even today I feel the symptoms (I8). We talk a lot, we talk very much, he likes talking to me for long times. Sometimes, when he sees that I'm angry, stressed, he hugs me, smells me, he says like this "don't be sad, my black girl". As I said, there are some days when any little thing we get strange with one another, we argue, but at the same time, we get reconciled and everything is fine (I12).

The speeches in this category refer to the feelings shared by the couples in this phase of the women's life. Mutual respect and understanding, and the exchange of affection, were observed through reference to complicity between couples. Although these elements were approached separately, it is noticeable that they converge in the speeches and they allude to the maintenance of affective relations in the couples.

\section{Influence of the climacterium on sexual activity and its interface with the marital relationship}

Changes in sexual activity were reported by the participants in this study. The decrease or absence of libido and, consequently, reduced frequency of sexual activity was pointed out by the women as a factor that directly influences the conjugal relationship. It was also noticed that the sexual relation occurs in a passive way, merely for the satisfaction of the spouse. Sex changes, about the days, many days pass and I even think it's good, we start getting old, and it changes, because the body changes. Only sex really, when we are young we do it every day and everything has to have limit, the desire decreases (I10). It affects the marital life a little, negativelly, because I do not feel much pleasure, you know. I don't feel like I want to do it. If it was my decision to make, if I ever got separated for some reason, I would not have the courage to look for anyone else. I do it (sex) but it is because of him; as for me, I would spend more than a month without it (I15).

It was also observed in the speeches mentions of the verb to cool down, in reference to the decrease in libido and lower regularity of sexual activity during the climacteric phase. We have sex sometimes, once a week. I cooled down. Because I've lost desire, he hardly looks for it. Times ago, it was a very hot thing, but because of this phase and the age coming, we cool down (I7). Very cold. Because that's the way it is, I do not know if it's because of this phase or I do not know if it's him, but it's that thing, if he does not look for me, I will not look either. I still feel like doing it, but it has cooled down a bit. I do not have that thing to be doing it everyday (I16).

Another factor reported by the deponents that caused changes in the couple's sexual activity during the climacteric period was dyspareunia, that is, the pain felt during the sexual act, referred to and related to the cessation of sexual contact in the couple's life. I'm not even having sex with my husband, because it hurts. When it's penetrating me, it hurts, I do not do it at all... Too bad, because when he wants to have relationship with me, I can not stand it because it hurts and bleeds (I4). We do not have sex, he respects me, I do not feel like doing it, and I will not take hormone just to get sick. The change is because I feel pain in the act and I will not get sick because of it (I14).

However, unlike most of the deponents of this category, there was a report that there was an improvement in pleasure in sexual intercourse during the climacteric period, motivated by the greater freedom to express sexuality, expressing a re-signification of this issue when detaching from judgments and stereotypes previously determined in youth. It is like that, I was 
not able to feel pleasure the way I feel today. The pleasure is greater now. I do not know if it is because of the mind that opens up, because times ago I was too demure, you know, nowadays, I feel free and it improved a lot. I have changed for better with respect to sex, I'm enjoying this phase now (I11).

\section{Estrangement in the conjugal relationship in- fluenced by the climacterium}

The indifference, estrangement, and lower exchange of affection in the marital relationship were reported by women. The estrangement may have occurred due to changes in the companion and changes in routine activities shared by the couple, which had repercussions on the weakening of the husband-wife relationship experienced by the couples. In the relationship, we used to be more, like that thing, affectionate. The change is because he used to kiss more, hug more. Now, we stay more like this, he on his own, me on my own, when he arrived home he used to hug me, he had those cute things, and we stopped doing this with each other. I will not say that it is only his fault, it's mine too, because things changed (I2). Our relationship was a bit shaken, because times ago, it was that thing, we would just lean on each other to feel the emotion and today, everything is different. We sometimes have to agree on certain points and it always affects, because that phase weakens our relationship (I6). Today, I do not care about him anymore, he started to come home wanting to abuse me, the other day, I called him, I told him, now he comes, takes a shower and stays on his own. He does not go out to places with me any more and I do not call him either. We used to like to go out together, but now he will not go any more, I go alone and he doesn't come. It has to do with this phase. It's all over, because he leans back and that's it (I13). He is not that person I know nine years ago. He changed, sometimes he demands from me, and I even stopped giving him affectionand being more delicate with him because he stopped, and I think like this, if he stopped, I will not reciprocate. Sometimes I talk to him about it: "Ah, you do not care for me, whatever", but it's about him really (I18).

\section{Discussion}

As a limitation of the study, we have the selection of the participants that could not be standardized by climacteric stage because, in the medical records, there was information that characterizes this phase only in a generic way. Another point is the methodological approach that does not allow generalizations regarding climacteric influences on marital relationships, since these are unique for each woman in the context in which they are inserted.

Despite these limitations, the findings of this study may contribute to changes in the approach to these women by health professionals, based on the understanding of the experiences and difficulties of the couple. In this sense, it is suggested to encourage the participation of men in consultations and educational activities on climacteric issues, in order to meet the demands of this multifaceted phase of women's lives.

In the climacterium, women go through physiological transformations of physical, hormonal and even psychosocial nature. Their daily life is influenced by changes that occur in this phase, which interfere with health, well-being and satisfaction ${ }^{(11-12)}$.

In the face of the biopsychosocial transformations experienced at this stage, women seek support from the family. In this context, in contemporary times, the spouse is the family member that deserves prominence. The image of the male is considered by the literature to be synonymous with stability, protection and is an important source of support for women during the climacteric period ${ }^{(13)}$.

However, it is important to note that this is a current trend, because power relations historically determined by gender issues have provoked tensions between men and women and prevented the construction of family projects supported by the complementarity of roles ${ }^{(9)}$.

Furthermore, the presence of the husband or partner can positively influence the climacteric experience of women. Women expect to find respect, intimacy, companionship and friendship in the partners during the climaterium, because when they are supported by their companions, they feel more encouraged to face the symptomatology of that period ${ }^{(14)}$. 
A mature relationship, built in the course of the conjugal life cycle and based on affection, respect and dialogue, contributes greatly to the positive experience of the climacteric phase, not only by the woman, but by the couple ${ }^{(15)}$.

A study carried out in São Paulo with husbands of climacteric women described that the companions recognized the physical and psychic changes in women during the climacteric phase, as well as their main needs during this period, which included respect, attention, companionship, dialogue, care and protection $^{(13)}$, attitudes that positively influence the relationship. This study is in line with the findings of the present research.

Similar findings were reported by researchers who studied the climacteric period from the perspective of men, in which dialogue was cited as a strategy for understanding the symptomatology of this period, as well as for maintaining the complicity and intimacy of the couple $\mathrm{e}^{(6,13,16)}$.

Thus, dialogue allows couples to identify the real difficulties in their relationship and approach feelings that can interfere in the married life. When men learn about the typical symptoms of this period, they tend to adopt assertive attitudes toward their wives, such as listening, caring, and giving more attention. By doing this they become an important source of social support, and a positive aspect for the women's experience, who feel calmer and safer ${ }^{(7)}$.

In the analyzed context, it was seen that among couples, the abovementioned positive attitudes refer to contemporary practices, anchored in sociocultural peculiarities characteristic of gender changes. The experience of this group with respect to the climacterium shows a new meaning to the affective connections and to the dichotomy based on sexual stereotypes, taking into account that there is an ongoing process of restructuring of conceptions about relationships built in the process of human interaction ${ }^{(2,9)}$.

It is common in the climacteric period for wo- men to exhibit symptoms such as hot flashes, insomnia, irritability, depressive mood, and hormonal changes accompanied by vaginal atrophies and reduced lubrication $^{(12)}$, which may reflect on sexual activity and influence the marital relationship.

Scholars claim that a woman's sexuality involves the complex interaction of sexual, hormonal, emotional functions, physical ability, partnership, and quality of the relationship. In middle-aged women, these factors articulate so as to determine the occurrence, frequency, and quality of sexual activity. Lower quality of sex and sexual satisfaction of women can be potentiated with the advance of age, especially in women who report intense symptomatology in the climacteric period, accompanied by body changes and emotional alterations ${ }^{(12,17-18)}$.

In this study, it was observed that changes in sexual activity occurred in the climacteric phase of the women. These change included, in most cases, reduced libido and frequency of sexual activity, besides dyspareunia, which negatively influenced marital relationships.

The loss of interest of climacteric women in sex has been mentioned in national and international stu$\operatorname{dies}^{(6,13,16)}$, related to typical complaints of this period such as loss of libido, loss of vaginal lubrication, and painful intercourse, as well as the false belief that loss of femininity is linked to aging ${ }^{(2,18)}$. Lower estrogen levels associated with the climacterium causes vasomotor symptoms, atrophy of the female sexual organ, leading to complaints that are correlated with this hormonal alteration ${ }^{(6)}$.

Lower sexual desire, from the perspective of the male gender, was related in a study to the loss of erotic attraction generated by the daily routine, as well as to the mutual distancing between the couple, which according to the study participants, was a normal stage of a long-term relationship and a natural event in the aging process ${ }^{(13)}$. Furthermore, there is a correlation between lower sexual desire and the cultural idea of 
men that women lose femininity after the cessation of menstruation, which is another important factor to consider $^{(16,19)}$.

The relationship between the climacterium and aging can motivate male sexual disinterest, favor the estrangement of the couple, and even break the bond between them. This reinforces the androcentric culture, focused on man's needs, most of which are of sexual nature, without taking into consideration emotional aspects $^{(6)}$.

It is pointed out that many barriers are not necessarily of sexual nature. They are obstacles and impasses that are expressed in the sexual experience, such as socially imposed customs and gender dynamics, with emphasis on taboos about aging, refusal of the woman's right to be sexually active, and the damage to virility, causing the couple conflicts over power relations built upon social norms ${ }^{(5,9,13)}$.

It was also possible to observe in this study that sexual intercourse exists, but in a passive way, to satisfy and give sexual pleasure to the partner. Many women believe that it is their role and responsibility to satisfy the spouses with sex, and this representation is based on social, historical and cultural impositions of female submission ${ }^{(2)}$. The speeches of the participants reiterate the gender relations based on the patriarchal domination of women by men, built on historical and cultural processes ${ }^{(9)}$.

International studies also address this idea of obedience and submission in sexual intercourse, where women experiencing the climacteric phase and experiencing symptoms of reduced libido are forced to have sexual intercourse only to satisfy their partners ${ }^{(19-20)}$.

An opposite view of the influence of the climacteric period on sexual activity was observed in this study, which elucidates new meanings for the body and for pleasure. This phase of the women's life can represent a moment of maturity, freedom and new discoveries, raising the possibility of improvement and renewal of sexual life. Feeling wanted, loved and understood is something that restructures the conceptions of femininity and promotes a greater involvement of the couple, making sexual relations more affective and pleasurable ${ }^{(2)}$.

The marital relationship can still be affected in the climacteric phase by barriers in the affective and relational bond of the couple. Estrangement was reported by some participants, being mainly related to changes and indifference on the part of the companions. The perception of "being a man" and "being a woman", in addition to its sociocultural construction, has contributed to the creation of behaviors and a way of living and expressing love, sex and care ${ }^{(6,9,19)}$.

Thus, both because of subjective issues and because of the lack of knowledge about this phase of women's life, some partners consider themselves impotent because they do not know how to act in the face of the symptomatology. They become passive and oblivious to the situation of the wife, leading to the estrangement of the couple, insecurity and loneliness in women who experience the climacteric period ${ }^{(6,13,17)}$.

\section{Conclusion}

Positive influences of the climacteric period were observed in conjugal relationships, since from the point of view of the participating women, at this stage of life, the spouse intensified attitudes of caring, companionship, understanding, respect and dialogue. On the other hand, they mentioned that due to the symptomatology, typical of this phase, there were changes in sexual activity that contributed to the estrangement in the conjugal daily life.

\section{Collaborations}

Carvalho ML contributed in the conception and design of the project, analysis and interpretation of data, writing of the article and final approval of the 
version to be published. Sales JCS collaborated in the in the conception, design, analysis and interpretation of data, writing of the article, critical review of the intelectual content, and final approval of the version to be published. Silva Júnior FJG and Parente ACM assisted in the relevant critical review of the intellectual content and final approval of the version to be published.

\section{References}

1. Moura EC, Gomes R, Falcão MTC, Schwarz E, Neves ACM, Santos W. Gender inequalities in external cause mortality in Brazil, 2010. Ciênc Saúde Coletiva. 2015; 20(3):779-88. doi: http://dx.doi. org/10.1590/1413-81232015203.11172014

2. Araújo IA, Queiroz ABA, Moura MAV, Penna LHG. Social representations of the sexual life of climacteric women assisted at public health services. Texto Contexto Enferm. 2013; 22(1):114-22. doi: http://dx.doi.org/10.1590/ S0104-07072013000100014

3. Instituto Brasileiro de Geografia e Estatística. Pesquisa Nacional por Amostra de Domicílio: síntese de indicadores 2015 [internet]. 2016 [citado 2018 abr 12]. Disponível em: https://biblioteca.ibge. gov.br/visualizacao/livros/liv98887.pdf

4. Ministério da Saúde (BR). Instituto Sírio-Libanês de Ensino e Pesquisa. Protocolos da Atenção Básica: Saúde das mulheres [Internet]. 2016 [citado 2018 abr 12]. Disponível em: http:// bvsms.saude.gov.br/bvs/publicacoes/protocolos_ atencao_basica_saude_mulheres.pdf

5. Santos SMP, Golçalves RL, Azevedo EB, Pinheiro AKD, Barbosa CA, Costa KNF. A vivência da sexualidade por mulheres no climatério. Rev Enferm UFSM. 2014; 4(1):113-22. doi: http:// dx.doi.org/10.5902/217976928819

6. Leite MT, Taschetto A, Hildebrandt LM, Van der Sand ICP. O homem também fala: o climatério feminino na ótica masculina. Rev Eletr Enferm. 2013; 15(2):344-51. doi: dx.doi.org/10.5216/ree. v15i2.15424
7. Yoshany N, Morowatisharifabad MA, Mihanpour $\mathrm{H}$, Bahri N, Jadgal KM. the effect of husbands' education regarding menopausal health on marital satisfaction of their wives. J Menopausal Med. 2017; 23(1):15-24. doi: doi.org/10.6118/ jmm.2017.23.1.15

8. Oliveira ZM, Vargens OMC, Acioli S, Santos RS. Nursing care in the climateric: demedicalizing perspective in primary health care. Rev Enferm UFPE on line. 2017; 11(2):1032-43. doi:https://doi.org/10.5205/1981-8963v11i2a13474p1032-1043-2017

9. Scott JW. Gênero: uma categoria útil de analise histórica. Educ Real [Internet] 1995 [citado 2018 maio 12]; 20(2):71-99. Disponível em: http:// seer.ufrgs.br/index.php/educacaoerealidade/ article/view/71721

10. Minayo MCS. Pesquisa social: teoria, método e criatividade. Petrópolis: Vozes; 2016.

11. Souza SS, Santos RL, Santos ADF, Barbosa MO, Lemos ICS, Machado MFAS. Woman and climaterio: conceptions of users of a basic health unit. Reprod Clim. 2017; 32(2):85-9. doi: https:// doi.org/10.1016/j.recli.2017.01.001

12. Alves ERP, Costa AM, Bezerra SMMS, Nakano AMS, Cavalcanti AMTS, Dias MD. Climacteric: intensity of symptoms and sexual performance. Texto Contexto Enferm. 2015; 24(1):64-71. doi: http:// dx.doi.org/10.1590/0104-07072015000590014

13. Rodolpho JRC, Quirino BC, Hoga LAK, Rosa PLFS. Men's perceptions and attitudes toward their wives experiencing menopause. J Women Aging. 2016; 28(4):322-33. doi: http://dx.doi.org/10.10 80/08952841.2015.1017430

14. Serpa MA, Lima AA, Guimarães ACP, Carrilo MRGG, Coura-Vital W, Veloso VM. Fatores associados à qualidade de vida em mulheres no climatério. Reprod Clim. 2016; 31(2):76-81. doi: https://doi. org/10.1016/j.recli.2016.04.001

15. Queiroz MAC, Lourenco RME, Coelho MMF, Miranda KCL, Barbosa RGB, Bezerra STF. Social representations of sexuality for the elderly. Rev Bras Enferm. 2015; 68(4):662-7. doi: http:// dx.doi.org/10.1590/0034-7167.2015680413i 
16. Hidiroglu S, Tanriover O, Ay P, Karavus M. A qualitative study on menopause described from the man's perspective. J Pak Med Assoc [Internet]. 2014 [cited 2018 may 22]; 64(9):1031-6. Avaliable from: http://jpma.org.pk/full_article_ text.php?article_id=6930

17. Nateri NS, Beigi M, Kazemi A, Shirinkam F. Women Coping Strategies towards Menopause and its Relationship with Sexual Dysfunction. Iran J Nurs Midwifery Res. 2017; 22(5):343-7. doi: https:// doi.org/10.4103/ijnmr.IJNMR_234_15

18. Waite LJ, Iveniuk J, Laumann EO, McClintock MK. Sexuality in Older Couples: Individual and Dyadic Characteristics. Arch Sex Behav. 2017; 46(2):60518. doi: http://dx.doi.org/10.1007/s10508-0150651-9
19. Bahri N, Latifnejad Roudsari R, Azimi Hashemi M. "Adopting self-sacrifice": how Iranian women cope with the sexual problems during the menopausal transition? An exploratory qualitative study. J Psychosom Obstet Gynaecol. 2016; 38(3):180-8. doi: dx.doi.org/10.1080/016748 2X.2016.1216962

20. Shukla R, Ganjiwale J, Patel R. Prevalence of postmenopausal symptoms, its effect on quality of life and coping in rural couple. J Midlife Health. 2018; 9(1):14-20. doi: http://dx.doi. org/10.4103/jmh.JMH_34_16 